\title{
A REVIEW OF A BASIC CONCEPT OF CELLULAR MANUFACTURING
}

\author{
Hayder Kareem Sakran \\ Chemical Engineering, Engineering College, AL Muthanna University, Samawa, Iraq \\ Hasanein Majeed Mahbuba \\ Chemical Engineering, Engineering College, AL Muthanna University, Samawa, Iraq \\ Ali Saleh Jafer \\ Chemical Engineering, Engineering College, AL Muthanna University, Samawa, Iraq
}

\begin{abstract}
Everyone can mention that some companies are more successful than other companies and they can meet their customers' requirement with almost no setup time and no waste. Cellular manufacturing gives materials and components ability to get a smooth flow during the production process. It also helps to increase the production velocity and make it more flexible. Cellular manufacturing pushes the company to produce a variant type of features at the same time and reducing the production time that can be taken for a single product. I will explain during this paper the concept which can help us to meet the customers' requirement with no waste. This paper will cover the basic concept of cellular manufacturing, which is the best way to apply lean manufacturing.
\end{abstract}

Key words: Cellular manufacturing, one-piece, lean manufacturing, Manufacturing flexibility.

Cite this Article: Hayder Kareem Sakran, Hasanein Majeed Mahbuba and Ali Saleh Jafer, A Review of a Basic Concept of Cellular Manufacturing. International Journal of Design and Manufacturing Technology 8(1), 2017, pp. 30-37.

https://iaeme.com/Home/issue/IJDMT?Volume=7\&Issue=4

\section{INTRODUCTION}

In 1950s, researchers found that identify and group the same parts of manufacturing should be done together to take a big advantage of their similarities during manufacturing and mass production. Using this approach helped to create a group of similar parts; this helps to reduce setup time. This technique of manufacturing was tamed as a group technology. [1], [2]

Cellular manufacturing is an application of the group technology concept which helps companies to build an aviary of production to their customers with as little waste as possible. [2]

The cellular manufacturing is arranged in a sequence that supports a smooth flow of material and component through the process with minimal transport or delay. 
Cellular manufacturing allows companies to provide their customers with the right product at the exact time. It does this by grouping similar product into families that can be processed on the same equipment in the same sequence.

Cellular manufacturing has big benefits, which include WIP reduction, space utilization, lead time reduction, productivity improvement, and quality improvement, enhance flexibility and visibility.

In this paper, I will explain the basic concept of cellular manufacturing, which is mainly in lean manufacturing.

\section{FOUNDATIONOFCELLULAR MANUFACTURING}

Cellular manufacturing is working on the principle that similar things should be manufactured similarly that means the things which have the same design attributes such as size, shape, etc..And manufacturing attributes such as length, diameter, surface finish, tolerance etc. These things should be together because that can help us to work with groups not with individual parts. Therefore, working with different groups is better than working with individual parts. We can make group by collecting the parts which are similar to one group such as machines, tools and equipment, which required processing these groups. So that can give us a big advantage. Consequently, if we collected these many individual parts to make one group that means we will have one problem, and it is easy to find a solution for this problem more than if we have many individual problems. So that will save time and effort. Cellular manufacturing is an approach which can be brought to tolerate in any plan where underlying similarities exist. It goes by grouping of parts and machines.

\section{CHARACTERISTICSOF CELLULAR MANUFACTURING}

In cellular manufacturing, the cell can meet the entire production requirement. Furthermore, these cells are self-efficient and self-managed. [1]

Manufacturing cell has got the following characteristics:

- Each cell has a particular set of family of components or products.

- Each cell is provided with all the machines and other facilities, which it needs to, complete its own particular family.

- Production targets for each cell are given as a whole and not separately of different individuals in the cell, and these targets are set by management in consultation with cell foreman and operators.

- Within the cells, there is a pool of labor with a certain degree of flexibility and a team of workers control each cell solely. The foreman or cell leader is in direct change of each cell, working solely for that group.

- Each cell does its own inspection and work scheduling.

\section{PRINCIPLEKEYSTHAT MAKELEANCELLBETTER THANTHETRADITIONAL JOB SHOP}

There are many things can make the lean cell better than the traditional job shop setup such as:

Flexibility: the key function-design requirement for manufacturing system is flexibility. Manufacturing cell is designed for flexibility. It is typically arranged in U-shape, so workers can move from a machine to machine, loading and unloading part, with the shortest walk distance. Machines in a cell are at least singlecycle automatics, so that they can complete the machine cycle untended, turning off automatically when finished. The cell usually includes processing needed for a complete part or assembly.

Manufacturing flexibility considers: 
- Adaptability to change of product design.

- Ability to reconfigure a manufacturing system or subsystem easily.

- Ability to adapt to product mix and volume change.

Using decouplers in manufacturing and assembly cells: Decouplers are placed between process and manual operations to provide cell flexibility, quality control, production control, and process delay. Between each machine is decoupler holding one part, processed and inspected, and ready to be pulled into a next process. Decouplers in the manned cell help the worker inspect a part while permitting the worker to move in the opposite direction of the part flow. Decoupler support material flow in the cell.

Product family: the customer may require more products, a different color mix, change in the product design, so cell system design can make many different types of product with a small setup time, but with the job shop system it will take a lot of time to produce a new production.

Multifunctional and multi-process workers: multifunctional means a worker can perform tasks related to setup, setup reduction, quality control, preventive maintenance, problem solving, and continuous improvement. To be a multi-process means a worker can operate various processes and/or carry out assembly tasks. A cell has multi-process workers who can operate more than one kind of process or multiple versions of the same process. They also carry out inspection and machine maintenance duties, making them multifunctional. Workers devise ways to eliminate setup time. Manufacturing and assembly cells eliminate the job shop concept of one person/ one machine. Therefore, increase worker productivity and utilization.

\section{LAYOUTOF CELLULAR MANUFACTURING}

The cell can be formed into a U-shape. Product moves in a counter-clockwise direction one piece at a time. One- piece technique can shorten the cycle time and changeover times Figure 1.

Machines in the cell are single - cycle automatics, so they can complete a machining cycle untended, and have it turn off automatically when it is finished with a processing cycle.

Unfortunately," in a cellular layout as the product-flow layout, a machine breakdown may still cause a work stoppage in the cell” [2].

Feeder line

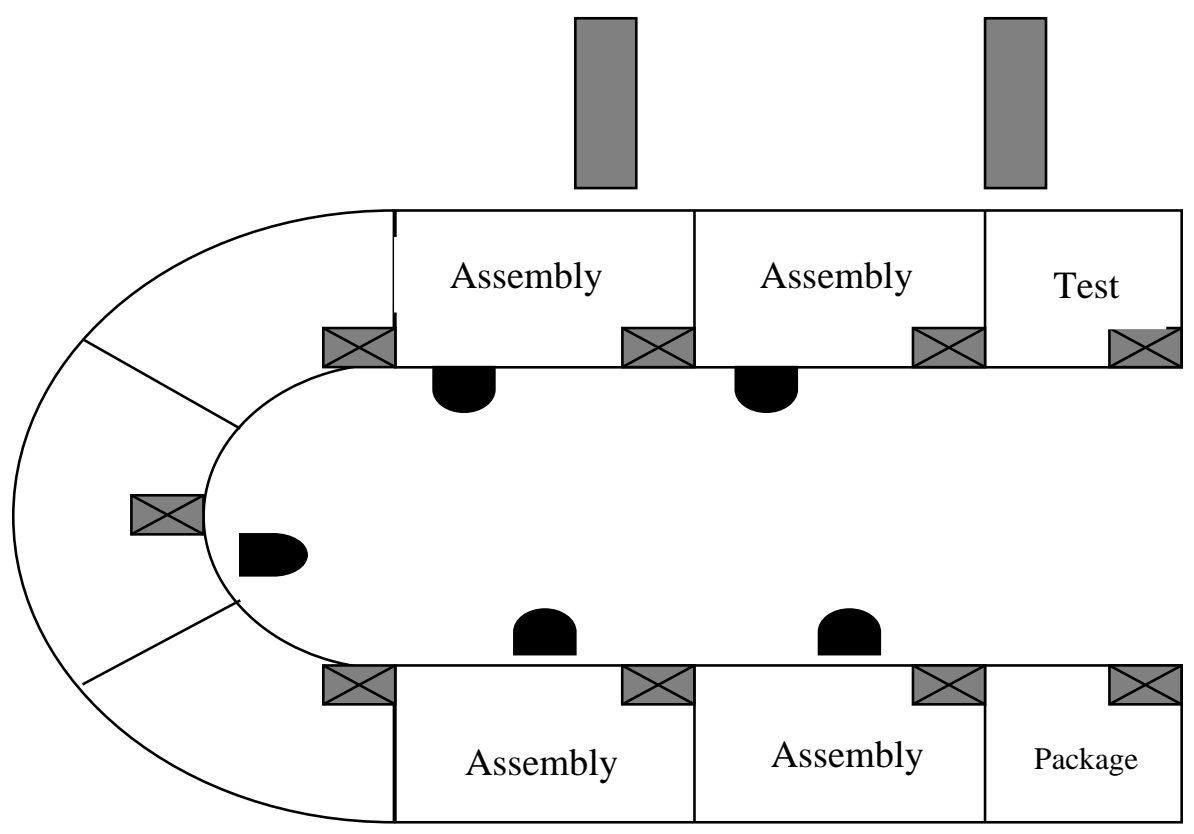

Figure 1 Manufacturing cell. [2] 


\section{CELLULAR MANUFACTURING OJECTIVE}

The primary objectives in implementing a cellular manufacturing are reduced. Therefore, some important objectives include:

- Reducing setup time by using part family tooling and sequencing.

- Reducing inventories.

- Reducing flow line (by reducing setup time and move times, wait time for movies and using smaller batch size).

- Increasing the labor and machine utilization.

- Maximization of output.

In addition, the cell appears as an approach that in more tendencies to teamwork. Manufacturing cells are natural candidates for just in time implementation.

\section{BENEFITSOF CELLULAR MANUFACTURING [3]}

Applying the concept of cellular manufacturing has a lot of benefits to the manufacturing which include:

- Reducing the number of product defects, it can be found the errors immediately and corrected.

- Reducing cycle time variability and line -balance constraints.

- Reducing WIP and finished goods inventories, producing only enough products to satisfy customer demand.

- Reducing or eliminating setup time.

- The flow will be smooth and faster through the operation.

- Reducing material handling costs and time.

- Reducing in manufacturing space required.

- Quality feedback between manufacturing and assembly operation is faster.

The summaries of the benefits of Cellular manufacturing comparing with job shop manufacturing shown in table1.

Table 1 The Benefits of cellular manufacturing after the First Two Months of Operation. [3], [4]

\begin{tabular}{|c|c|c|c|}
\hline Criteria & Job Shop & CMS & $\begin{array}{c}\text { Resulting } \\
\text { Improvement }\end{array}$ \\
\hline Work in process & $\$ 590,000$ & $\$ 116,336$ & $\$ 473,664(80 \%)$ \\
\hline Finished goods & $\$ 880,000$ & $\$ 353,167$ & $\$ 526,833(60 \%)$ \\
\hline Refractory supplies & $\$ 8,333 /$ month & 0 & $\$ 8,333(100 \%)$ \\
\hline Lead time & 14 days & 2 days & 12 days $(86 \%)$ \\
\hline Late orders & 100 & 4 & $96 \%$ \\
\hline Scraps & $22 \%$ & $14 \%$ & $8 \%$ \\
\hline Direct labor & 198 & 145 & 53 employees (27\%) \\
\hline Mfg. Space (sq. ft.) & 45,000 & 20,000 & 25,000 sq. ft. (56\%) \\
\hline
\end{tabular}




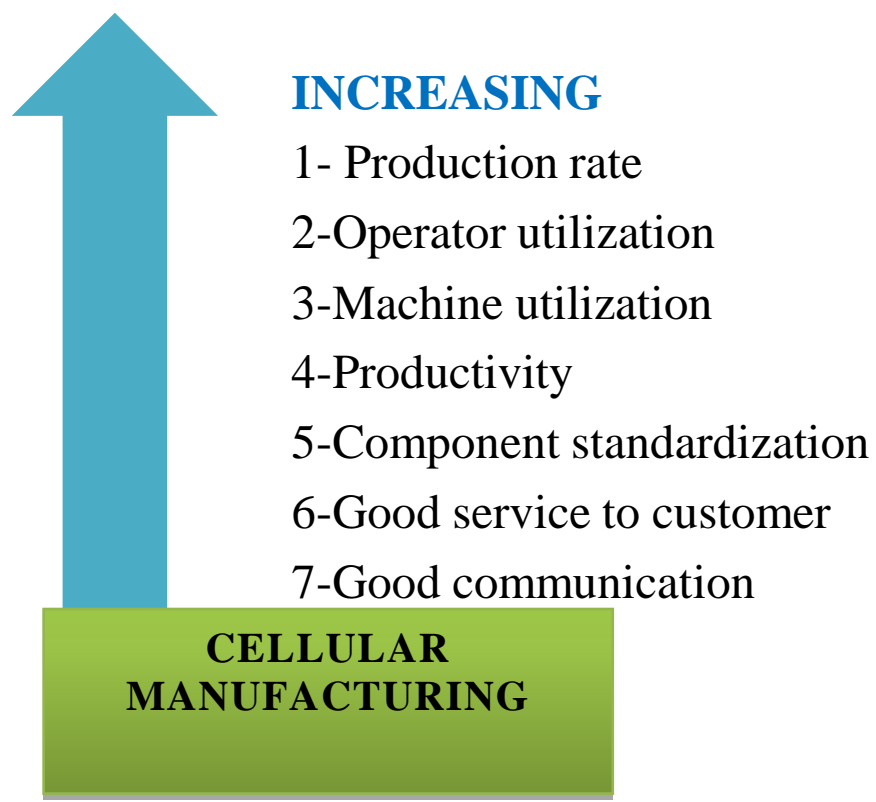

\section{REDUSING}

1-Material handling

2-Work-in-process inventory

3-Throughput time

4-Setup time

5-Space

6-Scrap

7-Waiting time

8-Lead time

9-Cycle time

Figure 2 Benefits of Cellular Manufacturing. [1] 
Table 2 The Benefits of the Cellular Manufacturing. [3], [5]

\begin{tabular}{|c|c|c|c|c|}
\hline Types of Benefit & $\begin{array}{c}\text { Number of } \\
\text { Responses }\end{array}$ & $\begin{array}{c}\text { Average \% } \\
\text { Improvement }\end{array}$ & $\begin{array}{c}\text { Minimum \% } \\
\text { Improvement }\end{array}$ & $\begin{array}{c}\text { Maximum \% } \\
\text { Improvement }\end{array}$ \\
\hline Reduction in throughput time & 25 & 45.6 & 5 & 90 \\
\hline Reduction in WIP inventory & 23 & 41.4 & 8 & 90 \\
\hline Reduction in material handling & 26 & 39.3 & 10 & 83 \\
\hline $\begin{array}{c}\text { Improvement of operator job } \\
\text { satisfaction }\end{array}$ & 16 & 34.4 & 15 & 50 \\
\hline $\begin{array}{c}\text { Reduction in number of } \\
\text { fixtures for cell parts }\end{array}$ & 9 & 33.1 & 10 & 85 \\
\hline Reduction in setup time & 23 & 32 & 2 & 95 \\
\hline Reduction in space needed & 9 & 31 & 1 & 85 \\
\hline Improvement of part quality & 26 & 29.6 & 5 & 75 \\
\hline $\begin{array}{c}\text { Reduction in finished good } \\
\text { inventory }\end{array}$ & 14 & 29.2 & 10 & 75 \\
\hline Reduction in labor cost & 15 & 26.2 & 5 & 40 \\
\hline $\begin{array}{c}\text { Increase in utilization of } \\
\text { equipment in the cells }\end{array}$ & 6 & 23.3 & 10 & 50 \\
\hline $\begin{array}{c}\text { Reduction in pieces of } \\
\text { equipment required to } \\
\text { manufacture cell parts }\end{array}$ & 10 & 19.5 & 1 & 90 \\
\hline
\end{tabular}

Table 3 The Performance Improvements. [3], [6]

\begin{tabular}{|c|c|c|c|c|}
\hline Performance Measure & $\begin{array}{c}\text { Number of } \\
\text { Responses }\end{array}$ & $\begin{array}{c}\text { Average \% } \\
\text { Improvement }\end{array}$ & $\begin{array}{c}\text { Minimum \% } \\
\text { Improvement }\end{array}$ & $\begin{array}{c}\text { Maximum \% } \\
\text { Improvement }\end{array}$ \\
\hline $\begin{array}{c}\text { Reduction of move } \\
\text { distance/time }\end{array}$ & 37 & 61.3 & 15 & 99 \\
\hline Reduction in throughput time & 40 & 61.2 & 12.5 & 99.5 \\
\hline $\begin{array}{c}\text { Reduction of response time to } \\
\text { orders }\end{array}$ & 37 & 50.1 & 0 & 93.2 \\
\hline Reduction in WIP inventory & 40 & 48.2 & 10 & 99.7 \\
\hline Reduction in setup times & 33 & 44.2 & 0 & 96.6 \\
\hline $\begin{array}{c}\text { Reduction in finished goods } \\
\text { inventory }\end{array}$ & 38 & 39.3 & 0 & 100 \\
\hline $\begin{array}{c}\text { Improvement in part/product } \\
\text { quality }\end{array}$ & 39 & 28.4 & 0 & 62.5 \\
\hline Reduction in unit costs & 38 & 16 & 0 & 60 \\
\hline
\end{tabular}




\section{COMPARSIMBETWEENTRADITIONAL JOB SHOPAND CELLULAR MANUFACTURING}

To make a comparison between traditional and cellular manufacturing, we can brief this comparison, according to a table which shown below.

Table 4 Comparison between Traditional Manufacturing and Cellular Manufacturing. [1]

\begin{tabular}{|c|c|c|c|}
\hline $\begin{array}{c}\text { SI. } \\
\text { No. }\end{array}$ & Criteria & $\begin{array}{c}\text { Traditional } \\
\text { Manufacturing }\end{array}$ & $\begin{array}{c}\text { Cellular } \\
\text { Manufacturing }\end{array}$ \\
\hline 1 & Capital investment & High & Low \\
\hline 2 & Inspection cost & High & Low \\
\hline 3 & Inventory cost & High & Low \\
\hline 4 & Space & High & Low \\
\hline 5 & Cycle time & High & Low \\
\hline 6 & WIP inventory & High & Low \\
\hline 7 & Waste( time, money, material) & High & Low \\
\hline 8 & Material handling & High & Low \\
\hline 9 & Machine utilization & Poor & High \\
\hline 10 & Team work & Poor & Excellent \\
\hline 11 & Control and Supervision & Poor & High \\
\hline 12 & Use of available skill & Poor & Excellent \\
\hline 13 & Communication & Poor & Excellent \\
\hline
\end{tabular}

\section{CONCLUSION}

The goal of this review is to get a basic understanding about the cellular manufacturing and how it can help the companies to improve its production and to reduce its waste. Therefore, the best concept to apply lean manufacturing is using a cellular manufacturing approach, which can help us to take the waste out. Furthermore, it has many effective ways to improve the manufacturing.

This paper has shown the basic concept of cellular manufacturing such as the objectives and the benefits of cellular manufacturing, which can achieve to meet the customers required.

\section{REFERENCES}

[1] BS. Parashar, Cellular Manufacturing Systems: An Integrated Approach. (PHI Learning Pvt. Ltd., 2008).

[2] J. T. Black, \&S. L. Hunter, Lean manufacturing and cell design(society manufacturing engineering, Dearborn, Michigan, USA, 2003).

[3] A. Mungwattana, Design of Cellular Manufacturing Systems for Dynamic and Uncertain Production Requirements with Presence of Routing Flexibility, doctoral diss., Virginia Polytechnic Institute and State University, 2000.

[4] G. A. Levasseur, M. M. Helms and A. A. Zink, "A Conversion from a Functional to a Cellular Manufacturing Layout at Steward, Inc.," Production and Inventory Management Journal, Vol. 36, No. 3, 1995, pp. 37-42.

[5] U. Wemmerlov, and N. Hyer, Cellular Manufacturing in the US Industry: A Survey of Users, International Journal of Production Research, 27(9), 1989, pp.1511-1530. 
[6] U. Wemmerlov, and D. John, Cellular Manufacturing at 46 User Plants: Implementation experiences and Performance Improvements, International Journal of Production Research, 35(1), (1997), pp. 29-49.

[7] N.Hyer, \& U. Wemmerlov, Reorganizing the factory: Competing through cellular manufacturing, Productivity Press, (2002).

[8] B. N. Shishir Baht, Cellular manufacturing- the heart of lean manufacturing, Advances in productions engineering and management, 3(1), (2008), pp171-180.

[9] Manufacturing, Cellular. One-Piece Flow for Work teams, ISBN: 156327213X. (1999).

[10] Sh. Ariafar, N. Ismail1, S. H. Tang, M. K. A. M. Ariffin and Z. Firoozi, Facility layout design for hybrid cellular manufacturing systems, International Journal of the Physical Sciences, 6(14), (2011), pp. $3551-3556$.

[11] N. Singh, Design of cellular manufacturing systems: An invited review, European Journal of Operational Research, 69, (1993), pp. 284-291.

[12] S. Saghafian, M. Reza Akbari Jokar, Integrative Cell Formation and Layout Design in Cellular Manufacturing Systems, Journal of Industrial and Systems Engineering,3(2),(2009), pp.97-115.

[13] L. María Alvarez López, Design and implementation of cellular manufacturing in a job shop environment, master thesis, Massachusetts Institute of Technology, 1997.

[14] Settapong Malisuwan, Jesada Sivaraks, Dithdanai Milindavanij and Wassana Kaewphanuekrungsi. Development of Mobile Financial Services in Thailand. International Journal of Management, 7 (1), 2016, pp. 15-25. 